\title{
MULTIPLE PROXIES FOR INVESTIGATING GLACIAL HISTORY OF ANTARCTICA FROM ODP SITES 696 \& 697
}

SUZANNE O'CONNELL (Wesleyan University) and JOSEPH ORTIZ (Kent State University)

\section{INTRODUCTION}

The Antarctic ice sheets and the Southern Ocean have played a central role in controlling global sea level and deep and intermediate water formation, upwelling intensity, and ultimately the storage and exchange of carbon dioxide with the atmosphere. Major goals in this Antarctic Pliocene and upper Miocene research include determining the presence and behavior of Antarctic ice sheets using the sediment record from ODP sediment cores and well-logs. This knowledge of the patterns and rates of past ice behavior can provide important analogues for predicting ice sheet retreat over the next few decades and centuries as atmospheric carbon dioxide levels exceed the present $410 \mathrm{ppm}$ $\mathrm{CO}_{2}$ and temperatures increase by more than 1 degree Celsius.

The Weddell Sea is one of the main formation sites for Antarctic Bottom Water and an outlet for about one fifth of Antarctica's continental ice volume, draining ice from both West and East Antarctica (Fig. 1). We chose the Weddell Sea embayment as the location for this study because there are many unresolved questions about ice-sheet history in this sector that can be readily addressed using diatom floral abundance, grain-size analysis and geochemical provenance techniques.

Sediment from two Ocean Drilling Program (ODP) Sites (113-696 and 113-697) and well logs from the circumAntarctic were examined (Figure 1). Both sites are dominated by terrigeneous sediment, contain no carbonate and small amounts of biosilica, primarily diatoms. Ice-rafted detritus and dropstones $(>1 \mathrm{~mm})$, indicators of ice-berg melting, and hence glacial history, are present at both sites. Core recovery is variable, ranging from $100 \%$ to no recovery at all.

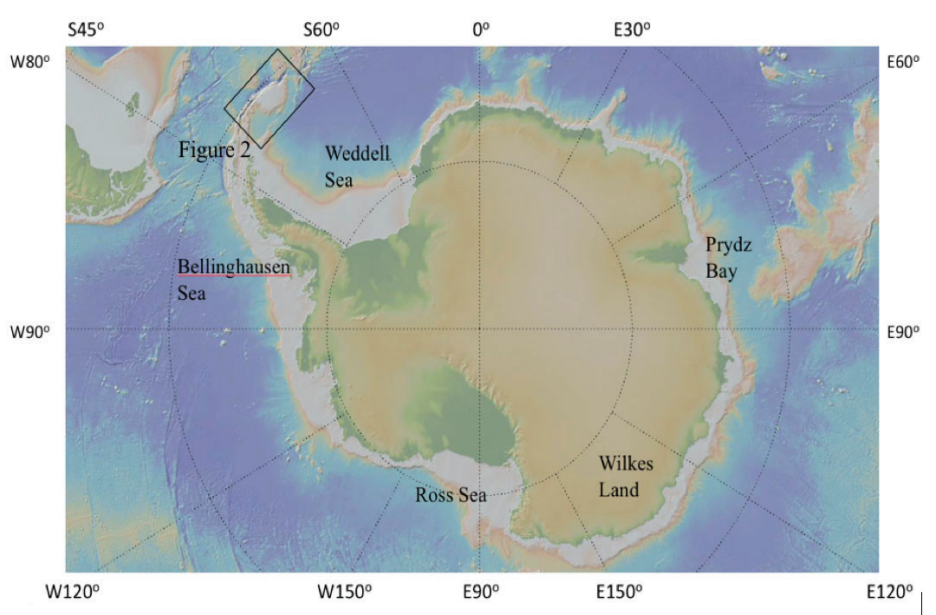

Figure 1. Polar projection of Antarctica produced with the GeoMapApp software depicting the location of the areas studied in this research. The two Leg 113 sites are shown in more detail in the insert (Figure 2). The well-logs of the circum-Antarctic sites are identified by basin. The IODP Wilkes Land sites are offshore of the land, in the ocean.

This research utilized a wide variety of sedimentological and geophysical techniques to describe the deposition of these circum-Antarctic sediments. Four different projects were completed as part of this study:

\section{1) Eduardo Centeno (Wesleyan University)} examined Pliocene diatom assemblages from Core 697B-14X (Figure 2), which we think represents sediment from Marine Isotope Stage (MIS) M2 (3.312-3.264 Ma) a Southern Ocean warming interval during which there was rapid turnover in diatom species.

2) Mark LePan (Colgate University) examined what-according to the shipboard initial results report-was thought to be Pleistocene diatoms from Core 113-696A-2H (Figure 2). His findings suggest that the core may well be Pliocene. 


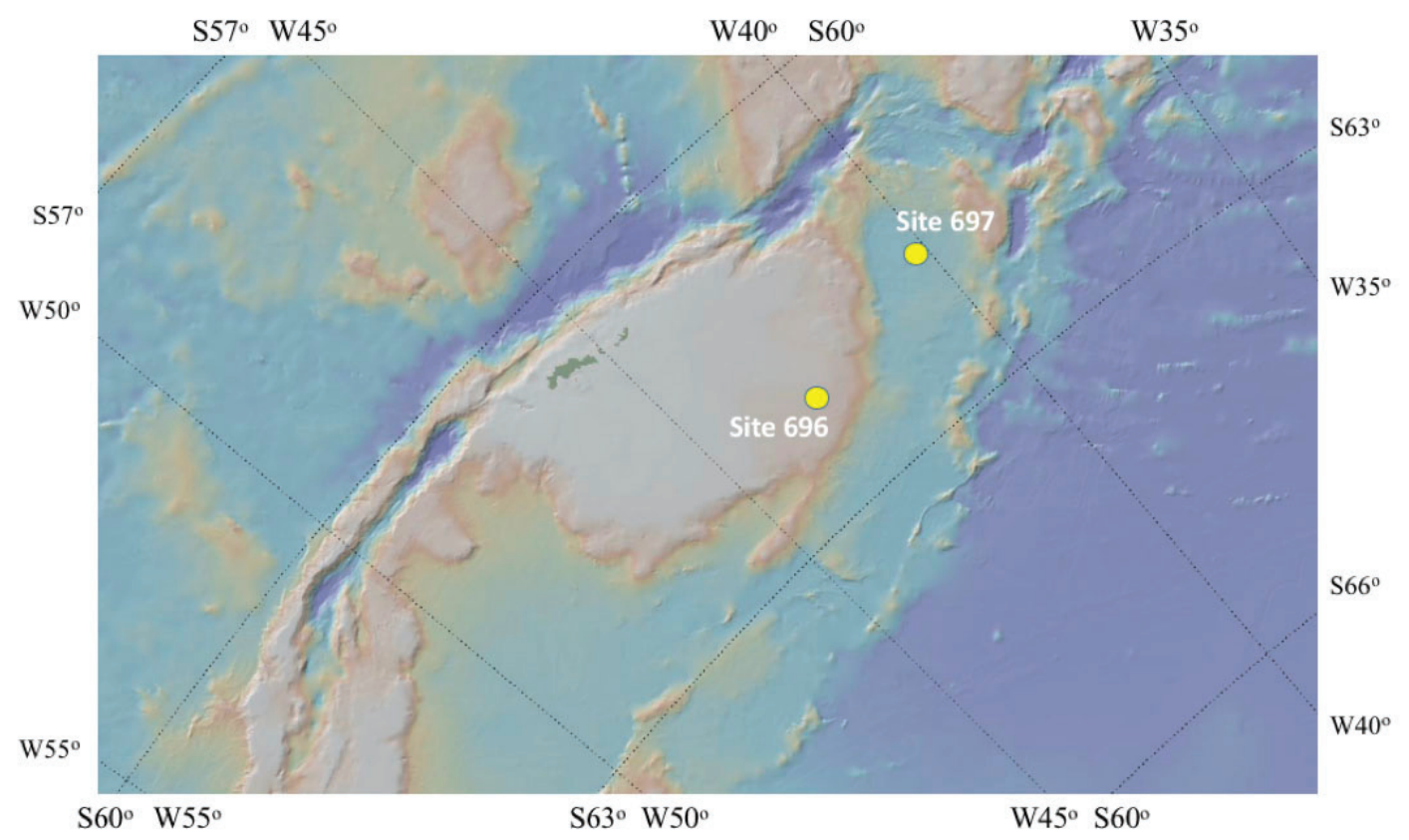

Figure 2. Polar projection of the insert shown in Figure 1 produced with the GeoMapApp software. The location of the two ODP Sites 696 and 697 are shown, clearly identifying that they were part of a depth transect, at 650 and $3480 \mathrm{~m}$ water depth respectively.

3) Forrest Lloyd (Beloit College) examined sediment chemistry and grain-size of the oldest section of Site 697, Cores 697B-31X and 32X (302.6-322.9 mbsf), with an estimated age around $5 \mathrm{Ma}$.

4) Andrew Hollyday (Middlebury College) conducted the widest ranging studies, examining split core measurements and geophysical well logs from several circum-Antarctic sites to identify the pace of lithologic variations.

In addition to these specific reports, data and samples collected by this Keck team will be available for further research projects in years to come.

\section{SPECIFIC RESEARCH PROJECTS}

Two diatom projects were undertaken as part of this research. The work of these investigators attests to how difficult diatom slide preparation and identification can be. Species identification requires using a high magnification microscope to identify the intricate patterns on both the edges and center of the rigid silica frustules. Diatoms reproduce both sexually and asexually.
Eduardo Centeno completed the diatom identifications for three samples in an interval that spans the crucial Marine Isotope Stage M2, a brief cooling event in the warmer Pliocene. His first two samples, at 697B-14X-5, 55-57 cm ( 3.29 Ma) and 697B-14X-4, $68-70 \mathrm{~cm}(\sim 3.27 \mathrm{Ma})$ are from the coldest part of interval $\mathrm{M} 2$, when benthic $\delta^{18} \mathrm{O}$ values were $\sim 3.7 \%$ o (LRO4, Lisiecki and Raymo, 2005). By the time the youngest sample, 679B-14X-2, 66-68 cm, (3.2 Ma) was deposited, the M2 isotope excursion had ended. The benthic $\delta^{18} \mathrm{O}$ values had lightened (warmed or freshened) to $\sim 3.1 \%$, indicating both rapid ice melting and probably concurrent warming of the deep ocean. The youngest sample, also had the highest weight percent biosilica, supporting the interpretation of a warmer, more productive, ocean. The decrease in Chaetocerous resting spores in the youngest (warmest) sample supports more open ocean conditions at 3.2 Ma, while sea-ice tolerant, Eucampia Antarctica, confirms the continued presence of sea-ice at this location. Centeno will continue this work as part of his senior honors thesis.

Mark LaPan also conducted a diatom research project. His project was to identify diatoms from Core 113-686A-2H, which according to the shipboard 
biostratigraphers was Quaternary in age (Barker, Kennett et al., 1988). He chose this interval because his research mentor specializes in Antarctic Pleistocene diatoms. Site 696, in $650 \mathrm{~m}$ water depth is the shallowest of a 3-site depth transect in the Jane Basin. As with the other Antarctic sites, it is dominated by terrigeneous sediment. To identify areas that were more likely to contain diatoms, magnetic susceptibility measurements were taken on the core. Areas with the lowest magnetic susceptibility are likely to have a higher percentage of biosilica and are likely to be the warmer intervals (Leventer et al., 1996). These intervals were preferentially sampled. Post-expedition examination of the samples by Gersonde and Burckle (1990), suggest that the Core spanned the Quaternary to late Pliocene. Since that paper was published, the diatom zonation has continued to evolve and two of the species identified by LaPan, Thalassiosira torokina and Thalassiosira inura are both now considered to be older than 2 and 3.5 million years respectively (Cody et al., 2008). With several Antarctic IODP expeditions in the austral summer of 2018 and 2019, it is likely that the diatom zonation will be further refined in the next several years, as additional diatom data and better paleomagnetics are combined to produce a revised diatom chronostratigraphy.

Forrest Lloyd examined the two oldest recovered cores from Site 697. Extensive work has been done during a previous Keck program on the younger Pliocene sections. The interval between 205.9 mbsf (Core 113-697B-20X) and 293.0 mbsf (Core 113-697B-30X) had very poor recovery $(30 \%)$. The resulting lack of continuity in this interval makes it a low priority to examine, hence the decision to go to the cores at the base of the hole.

The goal of this study was to examine sediments from the early Pliocene, a warmer interval, to see if ice-rafted sediment, based on ${ }^{40} \mathrm{Ar} /{ }^{39} \mathrm{Ar}$ age determinations of biotite and hornblende were sourced from closer locations (Williams et al., 2010) and if bottom currents were weaker based on mean sortable silt size determinations (McCave et al., 1995). Both of these measurements would support a warmer early Pliocene.

Cores 113-697B-31X and 32X (302.6-322.9 mbsf) were dated as lower Pliocene by the shipboard biostratigraphers (Barker, Kennett et al., 1988), relying primarily on radiolarian zonations (Lower Tau zone). These two cores were hampered by the lack of paleomagnetic reversals to provide an age determination and therefore a more accurate determination of sedimentation rates. The two closest reversals, occur at the top of C3N-3 and top of C3N-4 (Table 1). Pudsey (1990) also shows a reversal at $261 \mathrm{mbsf}$, but there is no core at that depth. But if that depth is used, it suggests an even higher sedimentation rate for Cores $31 \mathrm{X}$ and $32 \mathrm{X}$. Given this constraint, there was the option of extrapolating the average sedimentation rate for the upper part of the core $(6.8 \mathrm{~cm} / \mathrm{ky})$ or using the much higher sedimentation rate based on the two closest ages $(27 \mathrm{~cm} / \mathrm{ky})$, or the imaginary core age from 261 mbsf (Table 2). All three approaches show that by the base of the Core $32 \mathrm{X}$, the sediments are likely to be in the upper Miocene. The lower age of the radiolarian lower Tau zone was extended post- Leg 113 (Lazarus, 1990) and, does extend into the uppermost Miocene (5.5-4.2 my), so a Miocene age is possible and is in agreement with a higher sedimentation rate at the base of the hole.

Whether upper Miocene or lower Pliocene, the objective of this investigation was to contrast this time interval with the middle Pliocene. This research shows more variable IRD and more common contourite deposits in these cores than those of the middle-Pliocene. This clearly shows that glaciation as documented by IRD was occurring during this time interval and that bottom currents were strong enough to develop contourites. Additional work will continue with both the dating of the hornblendes and biotites.

Andrew Hollyday employed cyclostratigraphic analysis of continuous split core measurements and well $\operatorname{logs}$ to identify orbital forcing at selected circumAntarctic ocean drilling sites (Figure 1) and from that determined sedimentation rates. Although sedimentation rates are usually calculated from biostratigraphic and paleomagnetic data, at sites where such data is lacking, this is an alternative, first-order method to identify sedimentation rates.

The sedimentation rate calculations for Site 697 are based on the down core XRF measurements for seven Pliocene-age cores with good recovery. Collected in 1987, the cores have shrunk and cracked due to dehydration. To generate a sedimentation rate, the domi- 
Table 1. Paleomagnetic Boundaries for Site 697 Identified in Pudsey (1990) With Sample Information and Sedimentation Rates

\begin{tabular}{|c|c|c|c|c|c|}
\hline $\begin{array}{c}\text { Magnetic } \\
\text { boundaries }\end{array}$ & $\begin{array}{c}\text { Sample } \\
\text { identification }\end{array}$ & $\begin{array}{c}\text { Depth } \\
\text { (meters } \\
\text { below } \\
\text { seafloor) }\end{array}$ & $\begin{array}{c}\text { Gee \& } \\
\text { Kent } \\
(2007) \\
\text { age (Ma) }\end{array}$ & $\begin{array}{c}\text { Pudsey } \\
\text { (1990) } \\
\text { age (Ma) }\end{array}$ & $\begin{array}{c}\text { Sedimenta } \\
\text { tion rate } \\
\mathrm{cm} / \mathbf{k y r}\end{array}$ \\
\hline $\begin{array}{l}\text { Matuyama } \\
\text { chron, base / } \\
\text { C2AN-1, top }\end{array}$ & $\begin{array}{l}\text { 697B-10H-1, } \\
99-111 \mathrm{~cm}\end{array}$ & 105.7 & 2.608 & 2.47 & \\
\hline C2AN-2, top & $\begin{array}{l}\text { 697B-13X-3, } \\
119-121 \mathrm{~cm} ?\end{array}$ & 132.8 & 3.11 & 2.99 & 5.40 \\
\hline $\begin{array}{l}\mathrm{C} 2 \mathrm{AN}-2, \\
\text { base }\end{array}$ & $\begin{array}{l}\text { 697B-14X-1, } \\
49-51 \mathrm{~cm}\end{array}$ & 138.7 & 3.22 & 3.08 & 5.36 \\
\hline $\mathrm{C} 2 \mathrm{AN}-3$, top & $\begin{array}{l}\text { 697B-14X-7, } \\
39-41 \mathrm{~cm}\end{array}$ & 147.6 & 3.33 & 3.13 & 8.09 \\
\hline $\begin{array}{l}\text { Gauss chron, } \\
\text { base / } \\
\text { C2AN-3, } \\
\text { base }\end{array}$ & $\begin{array}{l}697 \mathrm{~B}-16 \mathrm{X}-4 \\
49-51 \mathrm{~cm}\end{array}$ & 162.25 & 3.58 & 3.4 & 5.86 \\
\hline C3N-1, top & $\begin{array}{l}\text { 697B-20X-4, } \\
29-31 \mathrm{~cm}\end{array}$ & 201 & 4.18 & 3.88 & 6.46 \\
\hline C3N-1, base & $\begin{array}{l}\text { 697B-21X-2, } \\
9-11 \mathrm{~cm}\end{array}$ & 207.5 & 4.29 & 3.97 & 5.91 \\
\hline $\mathrm{C} 3 \mathrm{~N}-3$, top & $\begin{array}{l}697 \mathrm{~B}-25 \mathrm{X}-2, \\
119-121 \mathrm{~cm}\end{array}$ & 247.2 & 4.8 & 4.4 & 7.78 \\
\hline C $3 N-3$, base & $\begin{array}{l}\text { ? No core at } \\
\text { this interval? }\end{array}$ & 261 & 4.89 & 4.47 & \\
\hline C3N-4, top & $\begin{array}{l}697 \mathrm{~B}-30 \mathrm{X}-2, \\
119-121 \mathrm{~cm}\end{array}$ & 295.7 & 4.98 & 4.57 & 26.94 \\
\hline
\end{tabular}

nant elemental components of the XRF data are found through a series of statistical steps, which allow the identification of the dominant elemental components varimax-rotated, principal components (VPCAs) - that explain the variance in the data. The VPCAs are then analyzed the same way as the well-log data from the other sites.

The down hole geophysical well logs (gamma-ray spectrometry and dual-induction resistivity) and the XRF VPCAs were analyzed using wavelet analysis, which detrends the data and uses frequency-domain transformations to decompose the time series into time-frequency phase space. The Pliocene cycles are identified by their power spectra and assigned Milankovitch periodicities (Hollyday, Figure 2). The strongest peak was assigned to either obliquity $(41,000$ years) or eccentricity $(100,000$ years) and in several cores precession $(23,000$ years) was also identified. The obliquity assignments are in agreement with prior Antarctic Pliocene investigations (Nash et al., 2009). Agreement between the periodicities identified by the different types of measurements confirms the validity of this technique (Hollyday, Table 1). Even where there is disagreement, e.g. an order of magnitude difference between the gamma-ray and resistivity 
Table 2. Age Calculations for the Top of Cores 31X and 32X Using Different Sedimentation Rates

\begin{tabular}{|l|c|c|c|c|l|c|}
\hline Location & $\begin{array}{l}\text { Depth } \\
(\mathrm{mbsf})\end{array}$ & $\begin{array}{l}\text { Age } \\
(\mathrm{Ma})\end{array}$ & $\begin{array}{l}\text { Age } \\
(\mathrm{Ma})\end{array}$ & $\begin{array}{l}\text { Age } \\
(\mathrm{Ma})\end{array}$ & $\begin{array}{l}\text { Sedimentation } \\
\text { rate }(\mathrm{cm} / \mathrm{kyr})\end{array}$ \\
\hline C3N-4 & 295.7 & & 4.98 & Top 31X & Top 32X & \\
\hline Top of core 31X & 302.6 & & 5.99 & 7.41 & 6.8 \\
\hline Top of core 32X & 312.2 & & & 5.24 & 5.59 & 26.9 \\
\hline & & & & 5.16 & 5.41 & 38.6 \\
\hline
\end{tabular}

sedimentation rates determined for Site 1059 in the Bellingshausen Sea, the assigned rates are still within the range of those determined by biostratigraphic and paleomagnetic techniques (Hollyday, Figure 3).

For the Weddell Sea, the focus of the rest the investigations, Hollyday's, average sedimentation rates where consistent within each core. Only in Cores 697B- $3 \mathrm{H}$ and $4 \mathrm{H}$ (37.1-56.5 mbsf), was there no obliquity signal identified. Sedimentation rates determined based on paleomagnetic age picks (Table 1, Figure 3) are surprisingly consistent, averaging between 5 and $8 \mathrm{~cm} / \mathrm{kyr}$, and in good agreement to his rate determinations of 4-8 cm/kyr (Hollyday, Table 1)

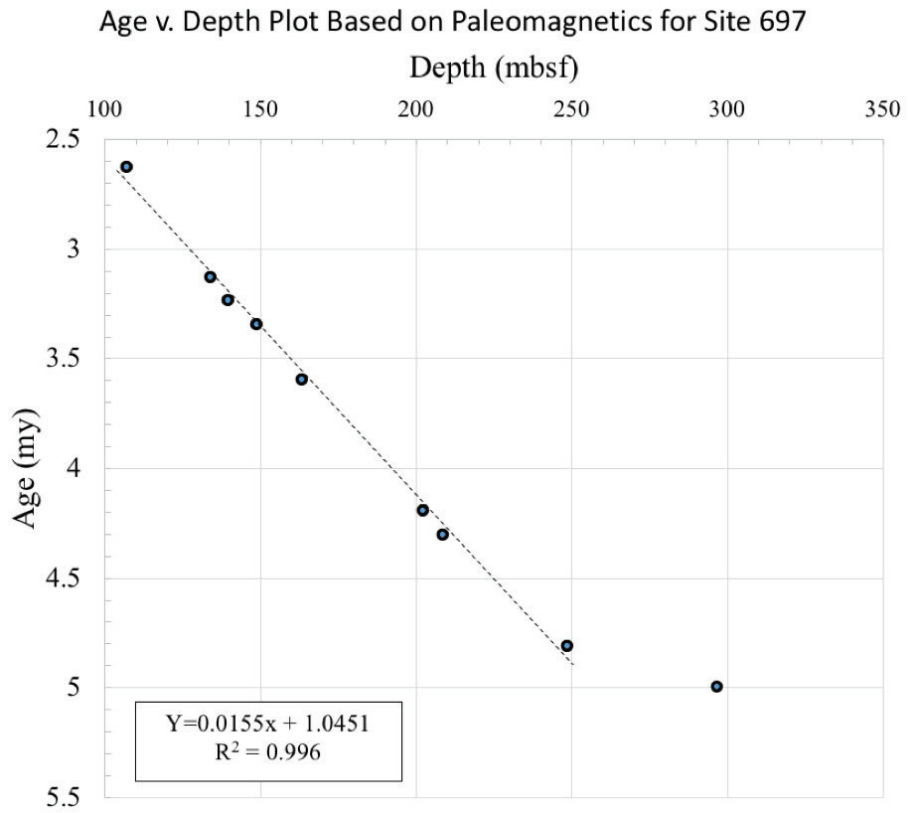

Figure 3. Sedimentation rate curve for Site 697 based on paleomagnetic age picks. The line through all but the oldest age pick shows a surprisingly constant sedimentation rate of 5.4-8.1 $\mathrm{cm} / \mathrm{kyr}$.

\section{SUMMARY}

These four studies provide a rich beginning to understanding Antarctic glacial history and the importance of using older ocean drilling program cores and well logs to understand this critical environment. Continued work on these cores and with this data will provide additional insight to describing and interpreting the glacial history of the Weddell Sea sector of Antarctica.

\section{ACKNOWLEDGEMENTS}

This material is based upon work supported by the Keck Geology Consortium and the National Science Foundation under Grant No. 1659322. We would like to extend thanks to the staff at the Gulf Coast Repository of the International Ocean Discovery Program, especially Phil Rumford, who facilitated our viewing and sampling of cores and Brian LeVay who taught us about the many complexities of core scanning XRF and coached us through the intracacies of collecting and processing, split core XRF measurements.

\section{REFERENCES}

Barker, P.F., Kennett, J. P., et al., (1988). Proc. ODP, Init. Repts., 113: College Station, TX (Ocean Drilling Program).

Cody, R.D. , Levy, R.H., Harwood, D.M., Sadler, P.M., (2008). Thinking outside the zone: Highresolution quantitative diatom biochronology for the Antarctic Neogene, Palaeogeography, Palaeoclimatology, Palaeoecology, 260 92-121. 
Gee, J.S., and Kent, D.V., (2007). Source of Oceanic Magnetic Anomalies and the Geomagnetic Polarity Timescale: Treatise on Geophysics, v. 5, p. 419-4607.

GeoMapApp, http://www.geomapapp.org/, accessed May 15, 2018

Gersonde, R. and Burckle, L.H. (1990) Neogene Diatom Biostratigraphy of ODP Leg 113, Weddell Sea (Antarctic Ocean). in Barker, P. R, Kennett, J. P., et al., Proc. ODP, Sci. Results, 113: College Station, TX (Ocean Drilling Program), v. 7, 61-789.

Lazarus, D., Middle Miocene to Recent radiolarians from the Weddell Sea, Antarctica, (1990) in Barker, P. R, Kennett, J. P., et al., Proc. ODP, Sci. Results, 113: College Station, TX (Ocean Drilling Program). v. 41, p.709-727.

Lisiecki, L., and Raymo, M. (2005). A PliocenePleistocene stack of 57 globally distributed benthic $\delta^{18} \mathrm{O}$ records, Paleoceanography, 20, pa1003. doi.org/10.1029/2004PA001071.

Leventer, A., E. W. Domack, S. Ishman, S. Brachfeld, C. McClennen, and P. Manley, (1996). 200300-year productivity cycles in the Antarctic Peninsula region: Understanding linkages among the Sun, atmosphere, oceans, sea ice and biota, Geol. Soc. Am. Bull., 108, 1626-1644.

McCave, I.N., Manighetti, B., and Robinson, S.G., (1995). Sortable silt and fine sediment size/ composition slicing: Parameters for palaeocurrent speed and palaeoceanography: Paleoceanography, v. 10 , p. 593-610.
Naish, T., Powell, R., Levy, R., Wilson, G., Scherer, R., Talarico, F., Krissek, L., Niessen, F., Pompilio, M., Wilson, T., Carter, L., DeConto, R., Huybers, P., McKay, R., Pollary, D., Ross, J., Winter, D., Barrett, P., Browne, G., Cody, R., Cowan, E., Carmpton, J., Dunbar, R., Dunbar, N., Florido, F., Gebhardt, C., Graham, I., Hannah, M., Hansaraji, D., Harwood, D., Hellings, D., Henrys, S., Hinnov, L., Kuhns, G., Kyle, P., Laufer, A., Maffioli, P., Magens, D., Mandernack,, K., McIntosh, W., Millan, C., Morin, R., Ohneiser, C., Paulsen, T., Persico, D., Raine, I., Reed, J., Riesselman, C. , Sagnotti, L., Schmitt, D., Sjunneskog, C., Strong, P., Taviani, M., Vogel, S., Wilch, T., Williams, T. (2009). Obliquity-paced Pliocene West Antarctic ice sheet oscillations. Nature, 458 (7236), 322-328. https://doi.org/10.1038/nature07867

Pudsey, C. J. (1990) Grain size and diatom content of hemipelagic sediments at Site 697, ODP Leg 113: A record of Pliocene-Pleistocene climate. in Barker, P. R, Kennett, J. P., et al., Proc. ODP, Sci. Results, 113: College Station, TX (Ocean Drilling Program), v.8, p. 111-120.

Williams, T., van de Flierdt, T., Hemming, S., Chung, E., Roy, M., Goldstein, S. (2010). Evidence for Iceberg Armadas from East Antarctica in the Southern Ocean during the Late Miocene and Early Pliocene." Earth and Planetary Science Letters, p. 351-361. 